Bolm Inst. oceanogr., S Paulo, $27(2): 45-55,1978$

\title{
A PRELIMINARY LABORATORY STUDY ON THE SALINITY AND TEMPERATURE TOLERANCES OF SOME MEDUSAE FROM THE SÃO PAULO COAST, BRAZIL
}

\author{
GLŌRIA SOARES MOREIRA \\ Instituto de Biologia Marinha and \\ Departamento de Fisiologia do Instituto de Biociêneias da \\ Universidade de São Paulo
}

\section{SYNOPS IS}

The salinity and temperature tolerances of some species of medusae were studied in the laboratory. The results showed the following order of tolerances in diluted seawater: Cirrholovenia tetranema, Clytia cylindrica and Eucheilota duodecimalis > Proboscidactyla ornata and Obelia spp. > Euphysora gracilis, Ectopleura dumortieri, Liriope tetraphylla and Cunina octonaria. In relation to the decrease of temperature, the following results were obtained: Ectopleura dromortieri, Euphysora gracilis, Obelia spp. and Proboscidactyla omata > Limiope tetraphylla > Cunina octonamia > Clytia cylindrica and Eucheilota duodecimalis. The results obtained in laboratory were discussed in relation to the distribution of the species in nature.

\section{NTRODUCTI ON}

Although Vannucci (1957 and 1963) has considered some species of medusae collected off the coast of the State of São Paulo as good indicators of the water masses which occur along the Brazilian coast, and Moreira (1973) has reported that discontinuity layers (haloclines and thermoclines) may act as barriers to their diurnal vertical migration, no attempt was made before knowing how the salinity and temperature affect these animals, in the laboratory. The great number of specimens required for the experiments and the difficulties which are usually encountered with in maintaining them in the laboratory, probably contributed to this lack of data. During the Summer of 1970, the medusae were particularly abundant in plankton samples collected in the channel, in front of the laboratory beach at a time when the author 
was staying at the Marine Biology Institute in São Sebastião. Taking advantage of this fact and of the facilities offered by the Marine Laboratory, some brief observations were then made on the effects of the salinity and the temperature on the survival and behavior of some medusae species.

\section{MATERIAL AND METHODS}

The plankton was collected in the São Sebastião Channel (23 $50^{\prime} \mathrm{S}$ and $\left.44^{\circ} 25^{\prime} \mathrm{W}\right)$, daily, from the 15 th to the 25 th February, 1970, with a Standard plankton net no 3. The salinity of the seawater in the Channel was around $35 \%$ and the temperature around $25^{\circ} \mathrm{C}$.

The plankton was brought alive to the Laboratory. The medusae were sorted out under a binocular, and maintained in a 2-1iter crystallizing dish filled with running seawater.

The experiments started about one hour after the collection. Several small culture dishes ( $10 \mathrm{~cm}$ diameter, $4 \mathrm{~cm}$ high) were filled with $100 \mathrm{ml}$ of filtered seawater, in the following combinations: $25^{\circ} \mathrm{C}$ temperature and 5,10 , $15,20,25,30$ and $35 \%$ salinities: $35 \%$ salinity and 5, 10, 15, 20 and $25^{\circ} \mathrm{C}$ temperature. The dilutions were obtained by adding distilled water to seawater. Salinities were determined by titrations against silver nitrate (Harvey, 1955).

At least 30 medusae of each species were used in the experiments, 10 for the temperature tolerance experiments, 10 for the salinity tolerance experiments, and 10 as control-animals. As much as possible, animals were used with about the same size and in the same stage of maturity. Different species were placed in different dishes. The medusae were transferred after each hour, to dishes with water either less saline or colder, successively. At the beginning of the experiments, results were recorded in duplicate, two identical ranges of salinity and temperature being used for the same conditions. As variation in survival and behavior was very smal1, it was assumed that a reasonably accurate estimation of the temperature-salinity tolerances of these species under laboratory conditions could be obtained from a single result. Experiments lasted 5 to 7 hours. Medusae were considered dead when they did not recover after returned to appropriated conditions $\left(25^{\circ} \mathrm{C}\right.$ and 
$35 \%$ salinity). During the experiments records were kept off the behavior of each animal. Each animal was rated as: A - With movements of swimming, involving pulsation of the bell usually associated with movement of the manubrium and somewhat shortened tentacles, occurring frequent1y, with short rest periods: $B$ - With movements of swimming occurring slower and less frequently than in $A ; C$ - Animals exhibiting the "crumple" reaction described by Hyman (1940), i.e., the medusae folds in the bell to the smallest possible compass, and sinks; $D$ - The animals present some slight movements of the umbre11a, but only after mechanical stimulation of the bell margin; $E$ - Animals completely quiet, lying upon the bottom of the dish, in a flaccid, unresponsive condition, although they are able to recover when placed in running seawater from the Channel; $F$ - Dead, animals quiet and without recovery when placed in running seawater.

\section{RESULTS AND DISCUSSION}

The results obtained in the experiments of tolerance to diluted seawater are presented in the Table I. In this series, the following species were studied: Ectopleura dumortieri and Euphysora gracilis (Anthomedusae); Obelia spp., Clytia cylindrica, Cirrholovenia tetranema and Eucheilota duodecimalis (Leptomedusae); Proboscidactyla ormata (Limnomedusae); Limiope tetraphylla (Trachymedusae); Cunina octonaria (Narcomedusae).

The movement of these medusae was found to be correlated in many respects with their morphology. The Anthomedusae swim pulsating the tall and narrow bell vigorously, while the Leptomedusae have a relatively thin and flexible bel1, which contorts with each pulsation. The medusae Obelia spp. and Cunina octonaria, the morphology of which recalls a saucer, swim with contraction of all the umbrella, opening it completely after each pulsation.

The species which tolerated the diluted seawater best were: Cirrholovenia tetranema, Clytia cylindrica and Eucheilota duodecimalis. Only CirrhoLovenia tetranema showed the "crumple" reaction in diluted seawater $(20 \%$ salinity). Clytia cylindrica and Eucheilota duodecimalis were found by Vannucci (1957; 1963) mainly in lagoon regions and coastal waters, but some 
occurrences of Clytia cylindrica in high salinities were registered in Fernando de Noronha Island (Vannucci, 1958) and in the Gulf of Naples (Vannucci, 1966). Cirrholovenia tetranema was found along the Brazilian coast only in coastal waters (Moreira, 1973). In the northwestern Atlantic, it was found in inshore waters, in the Beaufort Inlet ship channel, North Carolina (Allwein, 1967), but it occurs also in high salinities in the Indopacific region (Kramp, 1959), as well as in the Mediterranean Sea (Brinckman, 1965). Thus, the laboratory experiments, as well as the field data, point to a high degree of euryhalinity of these species. According to Vannucci (1963), they are coastal species that may expand oceanwards occasionally.

TABLE I - Salinity tolerances of some species of medusae (legend in the p. 47), at $25^{\circ} \mathrm{C}$

\begin{tabular}{|l|r|r|r|r|r|r|c|}
\hline Salinity ( $\%$ ) & 35 & 30 & 25 & 20 & 15 & 10 & 5 \\
Species & & & & & & & \\
\hline Ectopleura drmortieri & $10 \mathrm{~A}$ & $10 \mathrm{~A}$ & $10 \mathrm{~B}$ & $10 \mathrm{~B}$ & $10 \mathrm{D}$ & $10 \mathrm{~F}$ & - \\
Euphysora gracilis & $10 \mathrm{~A}$ & $10 \mathrm{~A}$ & $5 \mathrm{~A} 5 \mathrm{~B}$ & $10 \mathrm{~B}$ & $10 \mathrm{D}$ & $3 \mathrm{E} 7 \mathrm{~F}$ & - \\
Obelia spp. & $10 \mathrm{~A}$ & $10 \mathrm{~A}$ & $10 \mathrm{~A}$ & $10 \mathrm{~A}$ & $10 \mathrm{D}$ & $5 \mathrm{E} 5 \mathrm{~F}$ & - \\
Clytia cylindrica & $10 \mathrm{~A}$ & $10 \mathrm{~A}$ & $10 \mathrm{~A}$ & $10 \mathrm{~A}$ & $10 \mathrm{~B}$ & $10 \mathrm{D}$ & $2 \mathrm{E} 8 \mathrm{~F}$ \\
Cirrholovenia tetranema & $10 \mathrm{~A}$ & $10 \mathrm{~A}$ & $10 \mathrm{~A}$ & $7 \mathrm{~A} 3 \mathrm{C}$ & $10 \mathrm{~B}$ & $10 \mathrm{~B}$ & $6 \mathrm{E} 4 \mathrm{~F}$ \\
Eucheilota duodecimalis & $10 \mathrm{~A}$ & $10 \mathrm{~A}$ & $10 \mathrm{~A}$ & $10 \mathrm{~B}$ & $10 \mathrm{D}$ & $10 \mathrm{D}$ & $1 \mathrm{E} 9 \mathrm{~F}$ \\
Proboscidactyla ornata & $10 \mathrm{~A}$ & $10 \mathrm{~A}$ & $10 \mathrm{~A}$ & $10 \mathrm{~A}$ & $10 \mathrm{~B}$ & $5 \mathrm{E} 5 \mathrm{~F}$ & - \\
Liriope tetraphylza & $10 \mathrm{~A}$ & $10 \mathrm{~A}$ & $10 \mathrm{~A}$ & $3 \mathrm{~A} 7 \mathrm{~B}$ & $10 \mathrm{D}$ & $10 \mathrm{~F}$ & - \\
Cunina octonaria & $10 \mathrm{~A}$ & $10 \mathrm{~A}$ & $10 \mathrm{~A}$ & $10 \mathrm{~B}$ & $10 \mathrm{D}$ & $10 \mathrm{~F}$ & - \\
\hline
\end{tabular}

The following species occupy the seconde place in order of tolerance to diluted seawater, in the laboratory experiments: Obelia spp. and Proboscidactyla ornata. Obelia spp. are very frequent in coastal waters, although Moreira (1970) has registered also a great number of specimens in cold waters on the shelf (10 to $20^{\circ} \mathrm{C}$ ), with salinities ranging from 35 to $36 \%$. In the laboratory experiments, there was a decrease of the swimming movements only at $20 \%$. At $15 \%$ the specimens became very quiet and only after a mechanical stimulation presented slight contractions of the tentacles. The increase of the quantity of the water in the body of the animal was so great, 
that the medusae became biconvex. At $10 \%$ the movements stopped completely and the animals seemed all dead, but some of them were able to recover when placed again in appropriated conditions of salinity and temperature.

Proboscidactyla omata is more abundant in offshore waters (Vannucci, 1963; Moreira, 1970). It is quite tolerant to diluted seawater till $20 \%$ salinity. At $15 \%$ it slows down the swimming movements and at $10 \%$ it becomes completely quiet and unresponsive. Although the medusae seemed dead, some of them were able to recover in appropriated conditions of temperature and salinity. This species occurs in salinities around $37 \%$ in the Gulf of Naples (Vannucci, 1966). It is a good indicator of the shelf water mass along the Brazilian coast (Vannucci, 1957), although it was also found in coastal waters after strong winds or vertical mixing. According to Vannucci (1963), P. ormata may survive a month or more in mixed coastal and shelf water, and may even produce a few buds eventually it dies off. Dead or dying specimens are common in such environments. This species usually produces medusa buds the year round. During the laboratory experiments, it was observed that individuals with medusa buds when placed in stressful salinities, usually liberate the buds. This fact may be due either to a mechanical rupture by a greater hydratation of the tissues or an adaptive response which eventually would result in a possibility of the young to find suitable conditions to survive.

Euphysora gracilis was less tolerant to diluted seawater than the previous species. Thus, at $25 \%$ the swimming movements diminished and at $15 \%$ the medusae sank to the bottom completely quiet. The umbrella increased its volume showing less height and greater diameter than originally, the jelly becoming thicker. The manubrium elongated, surpassing the margin of the umbrella. At $10 \%$ most of the medusae died after a short time. Some field studies have demonstrated that this species is stenohaline, the preferred range being $35-36 \%$ salinity (Vannucci, 1963). Some occurrences in coastal waters are registered occasionally, after a strong southeasterly wind. Moreira (1973) verified that E. gracilis usually migrates vertically ascending from near the bottom to the surface at night, but when there is a halocline and coastal water is present above it, this less saline water acts as a barrier for the movement. 
The species less tolerant to diluted seawater were: Ectopleura dumortieri, Liriope tetraphylla and Cunina octonaria. In 1aboratory experiments, $E$. dumortieri at $25 \%$ o had slower and less frequent swimming movements than at $35 \%$. At $15 \%$ the specimens became completely quiet and there was an increase in the body volume due the absorption of the water. At $10 \%$, during the first minutes, there were some "crumple" reactions, and afterwards they died. According to Vannucci (1963), this is an euryhaline species that prefers salinity above $35 \%$. Off the Brazilian coast it is found all the year round. Kramp $(1930 ; 1933)$ recorded it from the North Sea in salinities between 34.78 and $35.01 \%$ and Küh1 (1962) from Cuxhaven, at $20 \%$ o salinity.

Although Liriope tetraphylla did not tolerate very low salinities, it survived quite well in salinities above $20 \%$. This species is very abundant along the Brazilian coast all year round. According to Vannucci (1957) this species can be found active and in large shoals in mangrove regions, probably because it tolerates concentrations of salinity lower than $33 \%$. But the most abundant catches were made in waters with salinity between 35 and $36 \%$ (Vannucci, op. cit. and Moreira, 1970). The diurnal vertical migration of $L$. tetraphylla was studied by Moreira (1973). This species, like Euphysora gracilis, does not migrate to the surface when low salinity water is present there.

Cunina octonaria is widely distributed in the warm parts of all oceans. off Brazil it was found in shelf and coastal waters, in salinities ranging from 33.5 to $36.9 \%$, but the richest hauls were always in salinities above $35 \%$ (Vannucci, 1957 and Moreira, 1973). In laboratory experiments, C. octonaria was tolerant to salinities above $20 \%$, but at $15 \%$ the animals became completely quiet and at $10 \%$ they died. According to Moreira (1973) neither the thermocline nor the halocline seems to interfere with the vertical movement of this species, which presents one of the most conspicuous examples of daily vertical migration in planktonic animals.

The results obtained in the experiments of tolerance to different temperatures are presented in Table II. In this series, the same species mentioned in the salinity experiments were studied with exception of Cirrholovenia tetranema, which was not caught in sufficient number. The species which toler- 
TABLE II - Temperature tolerances of some species of medusae (legend in the p. 47), at $35 \%$ salinity

\begin{tabular}{|l|r|r|r|r|c|}
\hline Temperature $\left({ }^{\circ} \mathrm{C}\right)$ & 25 & 20 & 15 & 10 & 5 \\
Species & & & & & \\
\hline Ectopleura dromortier & $10 \mathrm{~A}$ & $10 \mathrm{~A}$ & $10 \mathrm{~A}$ & $10 \mathrm{~B}$ & $10 \mathrm{E}$ \\
Euphysora gracilis & $10 \mathrm{~A}$ & $10 \mathrm{~A}$ & $10 \mathrm{~A}$ & $10 \mathrm{~B}$ & $10 \mathrm{E}$ \\
Obelia spp. & $10 \mathrm{~A}$ & $10 \mathrm{~A}$ & $4 \mathrm{~A} 6 \mathrm{~B}$ & $10 \mathrm{~B}$ & $10 \mathrm{E}$ \\
Clytia cylindrica & $10 \mathrm{~A}$ & $8 \mathrm{~B} 2 \mathrm{C}$ & $6 \mathrm{D} 4 \mathrm{C}$ & $5 \mathrm{D} 5 \mathrm{E}$ & $4 \mathrm{E} 6 \mathrm{~F}$ \\
Eucheilota duodecimalis & $10 \mathrm{~A}$ & $10 \mathrm{~B}$ & $10 \mathrm{~B}$ & $10 \mathrm{D}$ & $3 \mathrm{E} 7 \mathrm{~F}$ \\
Proboscidactyla ornata & $10 \mathrm{~A}$ & $10 \mathrm{~A}$ & $10 \mathrm{~A}$ & $10 \mathrm{~B}$ & $10 \mathrm{E}$ \\
Liriope tetraphylza & $10 \mathrm{~A}$ & $10 \mathrm{~A}$ & $10 \mathrm{~A}$ & $2 \mathrm{C} 8 \mathrm{D}$ & $1 \mathrm{~F} 9 \mathrm{E}$ \\
Cunina octonaria & $10 \mathrm{~A}$ & $10 \mathrm{~A}$ & $10 \mathrm{~A}$ & $10 \mathrm{C}$ & $2 \mathrm{~F} 8 \mathrm{E}$ \\
\hline
\end{tabular}

ated the cold temperatures better were: Ectopleura dronortieri, Euphysora gracillis, Obelia spp. and Proboscidactyla omata. It is known that Ectopleura dumortieri is an euryhaline and eurythermic species (Vannucci, 1957; 1963), but according to Moreira (1970) it prefers temperatures under $20^{\circ} \mathrm{C}$. It has the wide geographic distribution of a tropical to temperate species which extends into southern boreal regions. This species undergoes diurnal vertical migration, but only from the bottom layers till the mid-water layers when a thermocline is present (Moreira, 1973). This fact suggests that the species is unable to stand sharp temperature rises.

Euphysora gracilis is also an eurythermic species which prefers low temperatures. It undergoes diurnal vertical migration, and neither the thermocline nor the surface waters with temperatures around $22^{\circ} \mathrm{C}$ prevent the upward movement of $E$. gracilis to the surface during the night (Moreira, 1973). Off the Brazilian coast it is a good indicator of cold shelf waters (Vannucci, 1963; Moreira, 1970; 1973).

Adult specimens belonging to the genus Obelia can not be reliably determined down to species level, but apparently the specimens have a similar behaviour and tolerances. Gough (1905) recorded a definite diurnal migration in Obelia sp., noting that it was taken at the surface during the night. 
Bolm Inst. oceanogr., S Paulo, 27(2), 1978

Furnestin (1959) noticed that Obelia sp. was more abundant in day hauls than in night hauls in the Moroccan waters. Vucetic (1961) found Obelia dichotoma in the 10-20 m layer only at night and in the $20-30 \mathrm{~m}$ or deeper layers at noon in the Bay Veliko Jezero of the Island of Mljet. According to Moreira (1973) the thermocline may act as a barrier to the ascending movement of specimens of Obelia, probably because the species occurring along the Brazilian coast are unable to stand sharp temperature rises.

Proboscidactyza ornata is an eurythermic species, but it is more abundant in cold shelf waters along the south Brazilian waters (Moreira, 1970). The vertical migration of this species was noted previously by Vannucci (1957) and it was studied seasonally during several 24-hour periods by Moreira (1973). This author verified that the thermocline acted as a barrier to the migrants and she concluded that this eurythermal species, in spite of its adaptive capacity cannot withstand rapid changes in temperature.

The following species, Limiope tetraphylza, was also quite tolerant to low temperatures, since only at $10^{\circ} \mathrm{C}$ the specimens showed a decrease in the frequency of the swimming movements. In some stressful conditions (low temperature or very high salinities) these medusae presented an inversion of the umbrella and the pseudomanubrium becomes completely exposed. In spite of the fact that $L$. tetraphylza is widely distributed in the warm waters of all the oceans, there are several records of this species in waters with temperature lower than $20^{\circ} \mathrm{C}$ (Kramp, 1957; E1-Maghraby \& Halim, 1965; Repelin, 1965; Vannucci, 1966; Moreira, 1970). According to Vannucci (op. cit.) the occurrence of a great number of specimens and of breeding populations at low temperatures suggest that this warm water species can survive at least for a certain period in the water of temperatures lower than its optimum. Moreira (1970) have found greatest density $\left(260 \mathrm{spec} . / \mathrm{m}^{3}\right)$ in waters with $15.2^{\circ} \mathrm{C}$ temperature and the 79,914 specimens (67\% of the tota1) studied were collected in waters with temperatures lower than $19^{\circ} \mathrm{C}$. This species, besides the fact that it is quite eurythermic, is also able to stand a quick rise of temperature, because a sharp thermocline did not act as a barrier to its diurnal vertical movement (Moreira, 1973).

Cunina octonaria was less tolerant to low temperatures than L. tetraphyzza. In the laboratory experiments, the specimens tolerated temperatures 
above $15^{\circ} \mathrm{C}$ quite well. At $10^{\circ} \mathrm{C}$, the animals showed the "crumple" reaction and at $5{ }^{\circ} \mathrm{C}$ became completely quiet. Some specimens were able to recover when placed in temperatures above $20^{\circ} \mathrm{C}$. This species is more abundant in warm shelf waters (Moreira, 1970), but it can be collected in cold waters under the thermocline during the daytime (Moreira, 1973).

Clytia cylindrica and Eucheilota duodecimalis were the species less tolerant to low temperatures. At $20^{\circ} \mathrm{C}$, some specimens of Clytia cylindrica already showed the "crumple" reaction and most of them died at $5^{\circ} \mathrm{C}$. Eucheilota duodecimalis was more tolerant to decreasing temperatures till $15^{\circ} \mathrm{C}$, but most of the specimens died at $5^{\circ} \mathrm{C}$. Both these species are coastal and were more tolerant than the others to dilute seawater. This fact shows a good adaptive ecological correlation. The coastal species are more subject to less concentrated waters than the shelf species and this fact may explain why they are more tolerant to dilute waters. At the same time, they are not subject to wide variations of temperature (off the State of São Paulo coast) and this explains their relative stenothermy. The medusae living on the shelf, during their vertical migration, frequently have to meet the cold deep waters coming from the Falklands, and this fact may be correlated to their greater eurythermy when comparisons are made with coastal species.

\section{ACKNOWLEDGEMENTS}

I wish to thank Prof. Dr. Tagea $\mathrm{K}$. Björnberg for critically reading the manuscript and for going through the English text. My thanks are also due to Prof. Dr. Plínio Soares Moreira for valuable comments and suggestions.

\section{RESUMO}

A tolerância de värias espécies de medusas a valores decrescentes de salinidade e temperatura foi estudada em laboratório. Os resultados mostraram a seguinte ordem de tolerância em relação à água do mar diluída: cirrrholovenia tetranema, Clytia cylindrica e Eucheilota duodecimalis > Proboscidactyla omata, Obelia spp. > Euphysora gracilis > Ectopleura dromortieri, Limope tetraphylla e Cunina octonaria. Em relação à diminuição de temperatu- 
ra, os seguintes resultados foram obtidos: Ectopleura dumortieri, Euphysora gracilis, Obelia spp. e Proboscidactyla omata > Limiope tetraphylla > Cunina octonaria > Clytia cylindrica e Eucheilota duodecimalis. Estes resultados obtidos em laboratório foram discutidos levando-se em conta a distribuição dessas espécies na natureza.

\section{REFERENCES}

ALLWEIN, J. 1967. North American Hydromedusae from Beaufort, North Carolina. Vidensk. Meddr dansk naturh. Foren., 130:117-136.

BRINCKMAN, A. 1965. The life cycle of the medusa Cirrholovenia tetranema Kramp 1959 (Leptomedusae, Lovenellidae) with a hydroid of the genus Cuspidella Hincks. Can. J. Zool., 43:13-15.

EL-MAGHRABY, A. M. \& HALIM, Y. 1965. A quantitative and qualitative study of the plankton of Alexandria waters. Hidrobiologia, 25(1-2): 221-238.

FURNESTIN, M. D. 1959. Méduses du plancton Marocain. Révue Trav. Inst. (scient. tech.) Pêches marit., 23(1):105-124.

GOUGH, L. H. 1905. On the distribution and the migration of Muggiaca atlantica Cunningham, in the English Channel, the Irish Sea, and off the south and west coast of Ireland in 1904. Publs Circonst. perm. int. Explor. Mer, $29: 493-519$.

HARVEY, W. H. 1955. The chemistry and fertility of seawaters. Cambridge, Cambridge Univ. Press, 224 p.

HYMAN, L. H. 1940. Observations and experiments on the physiology of medusae. Biol. Bull. mar. biol. Lab., Woods Hole, 79:282-296.

KRAMP, P. L. 1930. Hydromedusae collected in the South western part of the North Sea and in the eastern part of the Channel in 1903-1914. Mém. Mus. r. Hist. nat. Belg., 45:1-55.

1933. Occasional notes on Coelenterate, II Vidensk. Meddr. dansk. naturh. Foren., 94:239-247.

1959. Some new and 1ittle-known Indo-Pacific medusae. Vidensk. Meddr. dansk. naturh. Foren., 121:223-259.

KtHL, H. 1962. Die Hydromedusen der Elbmündung. Abh. Verh naturw . Ver. Hamburg, NF, 6:209-232. 
MOREIRA, G. S. 1970. Físio-ecologia de hidromedusas (Cnidaria-Hydrozoa) do Atlântico Sul Ocidental. Tese de Doutoramento. Universidade de São Paulo, Instituto de Biociências, 99 p.

1973. On the diurnal vertical migration of Hydromedusae off Santos, Brazil. Publs Seto mar. biol. Lab., 20:537-566.

REPELIN, R. 1965. Quelques mëduses de 1'Ile Anno Bon (Golfe de Guinēe) . Cah. ORSTOM, sēr. Océanogr., 31(1):73-79.

VANNUCCI, M. 1957. On Brazilian Hydromedusae and their distribution in relation to different water masses. Bolm Inst. oceanogr., S Paulo, $8(1 / 2): 23-109$.

1958. Considerações em torno das Hydromedusae da região de Fernando de Noronha. Bolm Inst. oceanogr., S Paulo, 9(1/2):3-12.

1963. On the ecology of Brazilian medusae at $25^{\circ}$ lat. S. Bolm Inst. oceanogr., S Paulo, 13(1):143-184.

1966. Total net plankton volume and Hydromedusae from fixed stations in the Gulf of Naples. In: Barnes, H., ed.-Some contemporary studies in marine science. London, George Allen \& Unwin, p. 675-697.

VUCETIC, T. 1961. Vertical distribution of zooplankton in the Bay Veliko Jezero on the Island of M1jet. Acta adriat., 6(9):3-20.

(Received February 2/1977) 